\title{
Does control of mutant p53 by Mdm2 complicate cancer therapy?
}

\author{
Carol Prives $^{1,4}$ and Eileen White ${ }^{2,3}$ \\ ${ }^{1}$ Department of Biological Sciences, Columbia University, New York, New York 10027, USA; ${ }^{2}$ The Cancer Institute of New \\ Jersey, Center for Advanced Biotechnology and Medicine, Department of Molecular Biology and Biochemistry, Rutgers \\ University, Piscataway, New Jersey 08854, USA
}

Missense mutant forms of $\mathrm{p} 53$ are expressed at high levels in some human cancers and may contribute to oncogenesis. In this issue of Genes \& Development, Terzian and colleagues (pp. 1337-1344) describe a mutant p53 knock-in mouse in which normal tissues and some tumors have low levels of mutant p53 protein unless $M d m 2$ or $p 16^{I N K 4 A}$ are absent. Once stabilized, mutant p53 promotes metastasis. Therefore, therapies that release p53 from Mdm2 might have unwanted consequences when cells have sustained a mutation in $\mathrm{p} 53$.

The p53 protein is one of the most important factors that protects us from acquiring cancer. Not only is p53 one of the most frequently mutated genes in most major forms of human cancers, but p53-null mice develop cancers with virtually $100 \%$ frequency and a high proportion of cancer-prone Li-Fraumeni families bear a germline mutation in one of their p53 alleles (Olivier et al. 2002). The activity of p53 that is responsible for mediating these outcomes is its ability to serve as a sequence-specific transcriptional activator (Vogelstein et al. 2000). Analysis of wild-type p53 has revealed functions that are entirely consistent with its tumor-suppressive function: P53 is required for cells to undergo growth arrest, senescence, programmed cell death, and other tumor-protective outcomes (Prives and Hall 1999; Vousden and Lu 2002). P53 protein levels are increased following several types of cellular stress including DNA damage, leading to the induction of numerous target genes that regulate these various cellular responses (Appella and Anderson 2001). There is, however, another category of p53 target genes whose function is to regulate p53 itself, and the most well validated and studied of these is the Mdm2 protein (Fig. 1; Barak et al. 1993; Wu et al. 1993).

Mdm2 down-regulates p53 by two different modes: First, it binds to the transactivation domain of p53 and prevents it from serving as a transcriptional activator, and second, it targets p53 for proteasome-mediated degradation stemming from its ability to function as an E3

[Keywords: Metastasis; mouse model; gain of function; p53 stability] Correspondence.

${ }^{3}$ E-MAIL ewhite@cabm.rutgers.edu; FAX (732) 235-5795.

${ }^{4}$ E-MAIL clp3@columbia.edu; FAX (212) 865-8246.

Article is online at http://www.genesdev.org/cgi/doi/10.1101/gad.1680508. ubiquitin ligase (Iwakuma and Lozano 2003). The importance of $\mathrm{Mdm} 2$ in the negative regulation of p53 is underscored by observations that in both embryos and many somatic tissues, Mdm2 deficiency causes numerous cell and tissue types to undergo p53-dependent apoptosis (Jones et al. 1995; Montes de Oca Luna et al. 1995; Ringshausen et al. 2006; Toledo et al. 2006, 2007; Xiong et al. 2006, 2007; Maetens et al. 2007). Furthermore, it was reported recently that generating a knock-in mouse harboring Mdm2 mutated within its RING domain that disables its E3 ligase activity results in very early embryonic lethality, unless these mice also lack p53 (Itahana et al. 2007). These data show that degradation of p53 is the critical activity of Mdm2 required for holding p53 in check at least in early embryos.

The protein products of most tumor suppressors are usually underexpressed in various tumors. The p53 protein is quite unique in that regard. In a large proportion of tumors, high levels of missense mutant forms of p53 are present-far higher than the wild-type form of the protein in normal unstressed cells (Olivier et al. 2002). Furthermore, having detectable levels of p53 is often considered a biomarker for the occurrence of mutant p53 status in tumors. There are also myriad clinical studies correlating high levels of mutant p53 with more aggressive behavior of tumors and poorer outcomes (Petitjean et al. 2007). Thus, in its wild-type form, p53 is a tumor suppressor, but it is arguable that mutant forms of p53 actually function as oncoproteins (Fig. 1).

Comparison of human p53 with p53 from other species has revealed five highly conserved regions. The first of these (box I) spans residues 13-23 within its $\mathrm{N}$ terminus, and overlaps the well-studied Mdm2-interacting region where phenylalanine 19, tryptophan 23, and Leu 26 of $\mathrm{p} 53$ bind a deep pocket in the $\mathrm{N}$ terminus of $\mathrm{Mdm} 2$. The other four conserved regions (boxes II-V) are located within residues 100-300, which in the wild-type protein is a well-folded protease-resistant region called the core domain (Vogelstein et al. 2000). This region has high and specific affinity for DNA sites that conform to a welldefined consensus sequence. In the great majority of tumors that harbor a p53 missense mutation their mutations are located within the core domain, and such mutants display altered or completely inactive DNA binding and transactivation despite their higher levels in 
Figure 1. Control of both wild-type and mutant p53 protein turnover by $\mathrm{Mdm} 2$ and the therapeutic consequences. (A) Regulation of wild-type p53 in normal cells to suppress tumorigenesis. (B) $p 19^{A R F}$ loss releases $\mathrm{Mdm} 2$, promoting p53 turnover and tumorigenesis. $(C)$ Loss of $p 16^{I N K 4 a}$ inhibits Mdm2-mediated mutant p53 destruction and enhances tumorigenesis. Therapeutic interference with Mdm2-dependent degradation of wild-type p53 may also stimulate latent mutant p53 accumulation, thereby promoting tumorigenesis. In the absence of degradation of mutant p53 by $\mathrm{Mdm} 2$, the mutant p53 gain-of-function activity is revealed, promoting tumor metastasis (Jonason et al. 1996; Terzian et al. 2008). Please note that blue indicates loss of function.

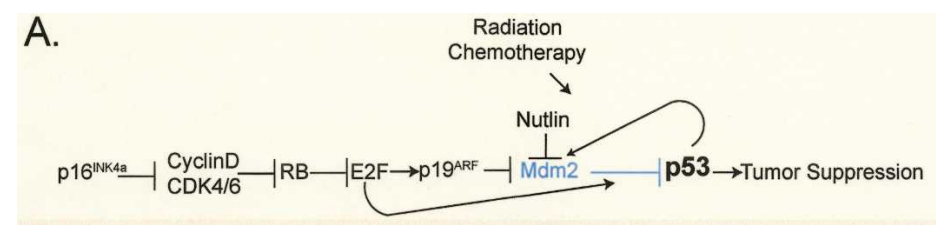

B.

$$
\text { p19ars }- \text { Mdm2 }-\mid \text { p53 }-\mid \text { Tumor Promotion }
$$

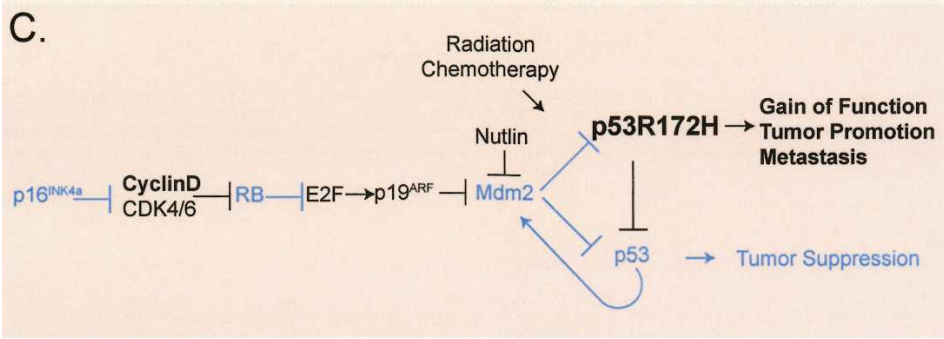

cells. Although most amino acids in the core domain have been found to be mutated in human tumors, among these are a set of six "hot spots" that together comprise nearly $40 \%$ of all of these mutations. The hot-spot mutations have been particularly well studied, and were shown to either impact direct DNA contacts of the core domain or alter its conformation (Joerger and Fersht 2007). These and other observations demonstrate the centrality of the normal DNA-binding function of wildtype p53 for its tumor-suppressive function.

Why do tumors contain so much more mutant p53 than normally seen with the wild-type protein? The simplest model is based on the relationship between p53 and Mdm2. The wild-type p53 protein has an extremely short half-life in normal cells that are free of stress, and p53 protein is extremely hard to detect by immunohistochemistry in noncancerous tissues. However unstable, in unstressed cells, the p53 protein is not inert and is capable of inducing sufficient $\mathrm{Mdm} 2$ protein expression for its own rapid degradation. In fact, having too much or too little $\mathrm{Mdm} 2$ can have profound consequences for mice and humans (Poyurovsky and Prives 2006). The end-point of the myriad stress signals that result in stabilization of p53 is disruption of the circuitry between p53 and Mdm2. Such signals either result in post-translational modifications that prevent p53 and Mdm2 from interacting, prevent Mdm 2 from degrading p53, or keep the two proteins apart by causing their differential cellular localization (Giaccia and Kastan 1998; Prives 1998; Appella and Anderson 2001). Since tumor-derived mutant forms of p53 cannot induce $\mathrm{Mdm} 2$, it has been assumed that their high levels in tumors were simply the result of their not being able to induce their degrader, Mdm2 (Fig. 1C).

Although clinical studies have supported the likelihood that high levels of mutant p53 are pro-oncogenic, these observations have been generally correlative in nature. More definitive support for mutants having an oncogenic gain-of-function phenotype was derived from studies with mouse models (Dittmer et al. 1993; Lang et al. 2004; Liu et al. 2004; Olive et al. 2004; Jackson et al. 2005; Song et al. 2007). In particular, two studies published in 2004 from the Lozano and Jacks groups ( Lang et al. 2004; Olive et al. 2004) reported results with knock-in mice in which either one or both wild-type p53 alleles were substituted by mouse equivalents of p53 hot-spot mutations. Such mice displayed a more diverse set of tumors than normally seen with p53 ${ }^{-/-}$mice. Since p53 oligomerizes, the gain-of-function activity of mutant p53 is thought to derive from a dominant-negative effect on wild-type p53 (Fig. 1C) and the p53-related proteins p63 and $\mathrm{p} 73$. A most unexpected finding about these knockin mice was that the levels of mutant p53 in their normal tissues were very low, similar to those of wild-type p53, while levels of mutant p53 were frequently high in their tumors. This posed two questions: Why are mutant forms of $\mathrm{p} 53$ that cannot induce Mdm2 not present at very high levels in normal tissues? And what allows them to be highly expressed in tumors? In this issue of Genes \& Development, the Lozano group (Terzian et al. 2008) has addressed these questions and reports some remarkable findings. Terzian et al. (2008) used their previously generated mice that were homozygous for a p53 mutant allele $\left(\mathrm{p} 53^{\mathrm{H} / \mathrm{H}}\right)$ in which Arg 172 is mutated to histidine. This mutant is the murine equivalent of a very well-studied conformational hot-spot human mutant $\mathrm{R} 175 \mathrm{H}$. Their mice develop tumors with approximately the same frequency as p53-null mice (i.e., 100\%). Terzian et al. (2008) show (again) that $\mathrm{p} 53^{\mathrm{H} / \mathrm{H}}$ mice have low levels of p53 in their normal tissues, but higher levels were detected in $79 \%$ of their tumors. Considering the low levels of mutant p53 in normal tissues and $21 \%$ of tumors, Terzian et al. (2008) speculated that either $\mathrm{Mdm} 2$ is present in sufficient amounts or that another degradation system is in place in normal cells and some tumors. In fact, other E3 ligases in addition to Mdm2 have been reported to be able to regulate p53 levels (Weger et al. 2002; Leng et al. 2003; Dornan et al. 2004; Rajendra et al. 2004; Chen et al. 2005; Esser et al. 2005; Yamasaki et al. 2007). On the other hand, Mdm2 has 
been reported to ubiquitinate and degrade tumor-derived mutant forms of p53 (Midgley and Lane 1997; Shimizu et al. 2006).

To determine if $\mathrm{Mdm} 2$ is involved in mutant p53 degradation, Terzian et al. (2008) crossed their p53 mutant mice to mice lacking both $\mathrm{Mdm} 2$ and p53 alleles. Since the progeny mice were born at the expected Mendelian ratio, this means that the $\mathrm{p} 53^{\mathrm{H} / \mathrm{H}}$ mice have lost wildtype $\mathrm{p} 53$ function (or have too little of it to have any impact without Mdm2). The key observation was that these mice now had higher levels (i.e., detectable) of p53 in most of their tissues (with liver being the exception). Although the survival curves of $\mathrm{p} 53^{\mathrm{H} / \mathrm{H}}$ did not differ from those of either p53-null or p53/Mdm2-null mice, the p53 ${ }^{\mathrm{H} / \mathrm{H}} / \mathrm{Mdm} 2$-null mice succumbed significantly earlier, having shorter life spans by $\sim 25 \%$. Furthermore, some of the $\mathrm{Mdm} 2^{-/-} / \mathrm{p} 53^{\mathrm{H} / \mathrm{H}}$ mice displayed metastatic tumors $(17 \%$ versus none when both alleles of $\mathrm{Mdm} 2$ are present). Thus, the answer to the first question is that $\mathrm{Mdm} 2$ is required for the maintenance of low mutant p53 levels in normal tissues. Importantly, the subsequent loss of Mdm2 function in cells with mutant p53 and the resulting mutant p53 accumulation promotes metastasis, the most lethal manifestation of cancer, necessitating careful consideration of these findings for therapy.

As mentioned above, treatment with DNA damaging agents leads to stabilization of wild-type p53, resulting from its reduced interaction with and degradation by Mdm2 (Fig. 1A,C). Terzian et al. (2008) asked whether DNA damage can also increase mutant p53 protein levels. To examine this, Terzian et al. (2008) subjected the different mice to whole-body irradiation and then examined cells from their spleens and thymuses. Indeed, levels of mutant p53 in spleen were induced significantly after irradiation of animals, while basal levels of p53 in the $\mathrm{p} 53^{\mathrm{H} / \mathrm{H}} / \mathrm{Mdm} 2^{-/-}$mice were already extremely high and did not increase after DNA damage. This provides further support for a role of $\mathrm{Mdm} 2$ in regulating levels of mutant p53. Interestingly, in a time-course experiment, while induced levels of wild-type p53 had subsided by 7 $\mathrm{h}$ after treatment, those of the mutant p53 did not and were still high at $15 \mathrm{~h}$. This suggests that the extra $\mathrm{Mdm} 2$ that is induced by wild-type p53 after DNA damage is a requirement for its eventual return to basal levels (Fig. 1A). It is also possible, however, that mutant p53 could interact uniquely with one or more proteins that could serve to stabilize or protect it from degradation after some forms of cellular stress.

The other question that the Lozano group (Terzian et al. 2008) addressed is: If p53 levels are kept low in normal cells, why is there so much more p53 protein in tumors? To address this, they built on the observation that the two protein products of the $p 16^{I N K 4 a}$ gene-the CDK inhibitor p16 and the Mdm2 inhibitor p19 ${ }^{\mathrm{ARF}}-$ both affect p53 levels by modulating Mdm2 (Fig. 1A). p16 does so through its ability to repress cyclinD/CDK phosphorylation of $\mathrm{RB}$, thereby inhibiting E2F. The outcome is that $\mathrm{p} 19^{\mathrm{ARF}}$ (an E2F transcriptional target) is prevented from blocking Mdm2-mediated degradation of p53 (Fig. 1A; Sherr 1998). Thus, loss of either $\mathrm{p} 16^{\mathrm{INK} 4 \mathrm{a}}$ or in- creased p19 $9^{\mathrm{ARF}}$ stabilizes p53, although there are also p19 ${ }^{\mathrm{ARF}}$-independent mechanisms for promoting p53 accumulation (Fig. 1). Indeed, when the $\mathrm{p} 53^{\mathrm{H} / \mathrm{H}}$ mice were crossed with mice lacking $\mathrm{p} 16^{\mathrm{INK} 4 \mathrm{a}}$, their progeny had both detectable p53 in normal tissues and significantly reduced survival, and again a subset of these mice (33\%) displayed metastatic tumors. The next logical step was to go back to the original tumors from the $\mathrm{p} 53^{\mathrm{H} / \mathrm{H}}$ mice to see if their tumors with stabilized p53 had lost p $16^{\text {INK4a }}$. In over half of these mice, this was the outcome. Further, an even higher proportion of these mice had increased cyclin D and phosphorylated RB.

So, the key findings from the Lozano group (Terzian et al. 2008) are that (1) despite their lack of ability to induce transcriptional targets including $\mathrm{Mdm} 2$, the p53 mutant $\mathrm{R} 172 \mathrm{H}$ is unstable in normal tissues but rises to high levels in the majority of, but not all, tumors in mice. (2) The key to mutant p53 instability is $\mathrm{Mdm} 2$, since mice lacking $\mathrm{Mdm} 2$ have much higher levels of mutant p53 in all tumors. (3) Mice with mutant p53 are more likely to produce metastatic tumors, which strongly supports the likelihood that it is the high levels of mutant p53 that are required for the metastatic phenotype. (4) Mutant p53 is induced by DNA damage in cells that contain, but not in cells that lack, Mdm2. (5) Loss of $\mathrm{p} 16^{\mathrm{INK} 4 \mathrm{a}}$ combined with $\mathrm{p} 53^{\mathrm{H} / \mathrm{H}}$ phenocopies loss of $\mathrm{Mdm} 2$ with $\mathrm{p} 53^{\mathrm{H} / \mathrm{H}}$ in stabilizing mutant $\mathrm{p} 53$, reducing survival and producing metastatic tumors.

The demonstration by Lozano and colleagues (Terzian et al. 2008) that low mutant p53 levels require Mdm2 in mice leads to the important issue as to whether mutant and wild-type forms of p53 interact with and are regulated similarly by $\mathrm{Mdm} 2$. This has been addressed recently in a study by Lukashchuk and Vousden (2007). These investigators built their study on previous findings that not only the $\mathrm{N}$ terminus but other regions of p53 have been shown to interact with Mdm2. Specifically, it was shown by Hupp's group (Shimizu et al. 2002, 2006 ) that a region located between boxes IV and V within the p53 core domain can interact with $\mathrm{Mdm} 2$. Since mutation of the core domain can change the conformation of p53, Lukashchuk and Vousden (2007) asked whether the interaction of $\mathrm{Mdm} 2$ with mutant p53 differs from that of wild-type p53. To approach this, they generated a set of deletion mutants, each lacking one of the five conserved regions in either a wild-type or missense mutant H175R background (the equivalent hotspot mutation used by Terzian et al. [2008]) and tested their ability to bind to Mdm2. Strikingly, using transient transfection assays in which mutants were coexpressed with $\mathrm{Mdm} 2$ followed by their coimmunoprecipitation, they were able to show that while wild-type p53 required box I exclusively for interacting with $\mathrm{Mdm} 2$, the codon 175 mutation allowed mutant p53 to interact with Mdm2 even when box I was deleted. Unexpectedly, the level of ubiquitination of mutant p53 was higher than that of wild-type p53 and did not correlate with mutant p53's binding to or even the presence of Mdm2, nor was it indicative of increased degradation. Further, deletion of box I had no impact on mutant p53 ubiquitination. 
Lukashchuk and Vousden (2007) made further relevant observations. First, a hyperubiquitinated mutant p53 is localized to the cytoplasm. Second, at least two other E3 ligases-CHIP (Esser et al. 2005; Muller et al. 2008) and Cop1 (Dornan et al. 2004) - contribute to the extensive ubiquitination of mutant $\mathrm{p} 53$. Third, mutant $\mathrm{p} 53$ lacking box I is still targeted for degradation by $\mathrm{Mdm} 2$ most likely because of a second post-ubiquitination function of Mdm2 in degrading its targets (Zhu et al. 2001; Jin et al. 2003; Brignone et al. 2004; Kulikov et al. 2006). Finally, while down-regulation of Mdm2 leads to similarly increased levels of mutant and wild-type p53 (supporting findings in the Lozano group's (Terzian et al. 2008) mouse mutant phenotypes), treatment of cells with a compound (Nutlin) that disrupts the Mdm2-p53 interaction by occluding the binding pocket (Vassilev 2007) had a much larger impact in stabilizing wild-type p53 than mutant p53 (Lukashchuk and Vousden 2007). Note, however, that there was still some increase in mutant p53 protein in Nutlin-treated cells, showing that box I in the mutant contributes to its binding to Mdm2.

Taken together, clear predictions and unanswered questions emerge from the realization that $\mathrm{Mdm} 2$ degrades both wild-type and mutant p53, and that p53 mutational status in tumors may dictate the response to therapy in more ways than previously realized. Moreover, the presence of unstable, latent mutant p53 in premalignant tissues and tumors that is still under the control of Mdm2-mediated degradation means that assessing p53 mutational status will require more than merely assessing p53 levels as a guide to predict therapeutic outcome. Indeed, $21 \%$ of tumors in $p 53^{H /+}$ and $p 53^{H / H}$ mice had latent p53 (Terzian et al. 2008), and mutant p53 is found in premalignant human skin lesions (Jonason et al. 1996). This suggests that mutant p53 is not always readily apparent, complicating therapies dependent on inducing wild-type p53.

Are there other means of inactivating $\mathrm{Mdm} 2$ in tumors? Increasing p19 $19^{\mathrm{ARF}}$ is clearly an important mechanism to stabilize mutants in tumors, and aside from loss of $\mathrm{p} 16^{\mathrm{INK} 4 \mathrm{a}}, \mathrm{Mdm} 2$ itself may form negative feedback loops regulating its own inactivation. For example, $\mathrm{Mdm} 2$ is able to elicit the proteasomal degradation of p21 (Jin et al. 2003; Zhang et al. 2004) and of RB (Sdek et al. 2005; Uchida et al. 2005), which would in turn lead to induction of p19 $9^{\mathrm{ARF}}$. Alternately, recent evidence of activated DNA damage stress signaling pathways in tumors may result in reducing the ability of $\mathrm{Mdm} 2$ to degrade either wild-type or mutant p53 (Bartkova et al. 2005; Gorgoulis et al. 2005).

What is the basis for mutant p53 gain of function? It has long been assumed that mutant p53 is not neutral in cancer. At least two different mechanisms have been identified that provide plausible explanations for how mutants might be oncogenic. In the first case, evidence has accumulated that a subset of mutant forms of $\mathrm{p} 53$ not only can inhibit wild-type p53 (Fig. 1C), but also can down-regulate the p53 family members p63 and p73 and reduce their ability to cause apoptosis ( $\mathrm{Li}$ and Prives 2007). Alternately, mutant p53 may be involved in acti- vation of proproliferative genes or repression of growthinhibiting genes (Weisz et al. 2007). Indeed, it is possible that, depending on the cellular context, mutant p53 proteins may participate in these and other processes that promote tumorigenesis.

Finally, what is the implication of the findings of Terzian et al. (2008) for therapeutic approaches? About half of all human tumors have wild-type p53 and, in some cases, also high levels of Mdm2. Now we have a greater appreciation that there is an additional subclass of tumors that may have latent mutant p53 that can be stabilized and potentially promote tumorigenesis upon inhibition or loss of Mdm2. This category of tumor cells may display the opposite of the desired response to therapeutic manipulation. Going forward will require clarification of key issues.

Will targeting Mdm2-mediated p53 degradation be problematic in cancer therapy? Until now, the common wisdom has been that therapeutic strategies that either inhibit the interaction between $\mathrm{p} 53$ and $\mathrm{Mdm} 2$ or block the ability of $\mathrm{Mdm} 2$ to degrade p53 might have the outcome of augmenting the ability of wild-type p53 to kill tumor cells, perhaps in combination with more conventional chemotherapeutic drugs (Lain and Lane 2003; Fischer and Lane 2004; Issaeva et al. 2004; Vassilev 2007). For example, a compound called Nutlin binds to those residues in Mdm2 that normally contact the $\mathrm{N}$ terminal region of $\mathrm{p} 53$, and treatment of transformed cells bearing wild-type p53 with Nutlin leads to a dramatic increase in p53 levels and activity (Vassilev et al. 2004). This compound or others such as peptides or peptidominetics that disrupt the interaction of p53 with $\mathrm{Mdm} 2$ is considered to be a very promising approach toward releasing wild-type p53 from the jaws of Mdm2 in tumors and allowing it to arrest or kill tumor cells. Yet, given the likely pro-oncogenic impact of having high levels of mutant p53, releasing mutant p53 from degradation by $\mathrm{Mdm} 2$ might have the very opposite effect, possibly actually promoting tumorigenesis! Treatment of the $\mathrm{p} 53^{\mathrm{H} / \mathrm{H}}$ mice with Nutlin would be a first step to resolving this issue. The results of Lukashchuk and Vousden (2007) may also provide some hope in that regard. Their data indicate that at least some mutants interact differently from wild-type p53 with $\mathrm{Mdm} 2$, and that treatment with Nutlin might not be as deleterious to tumors with such mutants. But how common this is among the various tumor-derived mutant forms of p53 remains to be determined.

Will conventional chemotherapy and radiation that activate wild-type p53-thereby facilitating tumor regression-also activate latent mutant p53 in human tumors and promote tumor progression? As latent mutant p53 responds similarly to wild-type p53 by accumulating in response to irradiation (Terzian et al. 2008), the expectation is that similar results will be found for chemotherapy that stimulates p53 accumulation. If so, this not only may render chemotherapy ineffective, but may reveal the p53 gain-of-function activity and provide an advantage to tumor growth (Fig. 1C). This, however, can be tested using the $\mathrm{p} 53^{\mathrm{H} / \mathrm{H}}$ mouse model. 
Will assessment of p53 status, wild-type, mutant, and latent mutant, be essential to determine therapeutic outcome? If latent mutant p53 induction in response to therapy is indeed problematic, assessment of latent p53 in human tumors may be essential prior to treatment. Implementing this may be difficult, as detection of p53 protein levels by immunohistochemistry cannot distinguish between wild-type and mutant proteins, as mentioned above.

Does Mdm2 also degrade other mutant forms of p53? It appears that $\mathrm{Mdm} 2$ regulates the p53 $\mathrm{R} 172 \mathrm{H}$ mutant somewhat similarly to wild-type p53, but whether other p53 mutant forms are also regulated in this way remains to be determined. If they are, then the challenge will be to distinguish wild-type from latent mutant p53 in those tumors with low p53 levels. If other p53 mutants are not degraded by $\mathrm{p} 53$, then that would necessitate identification of the particular p53 mutation to guide therapy. Additional mouse models with knock-in p53 hot-spot mutations may help to distinguish between these possibilities.

Are the other E3 ligases for p53 similarly specific for mutant p53, or do some preferentially degrade wild-type or mutant forms? As mentioned earlier, Mdm2 is not the only E3 ligase capable of targeting p53 for proteasomemediated degradation. Indeed, CHIP- and Cop1-like Mdm2 can target mutant p53, but whether other E3 ligases such as Topors (Rajendra et al. 2004), PIRH2 (Leng et al. 2003), and ARF-BP1 (Chen et al. 2005) also target mutant p53 is not clear. Determining the specificity and circumstances under which these alternate p53 E3 ligases function may be informative. Similarly, identification of deubiquitinating enzymes (DUBs) such as HAUSP that remove ubiquitin and promote stability of wild-type (Li et al. 2004), but potentially not mutant p53, would be an alternate approach.

What are the tissue-specific determinants regulating wild-type and mutant p53 turnover? Notably, deficiency in Mdm2 was not sufficient for mutant p53 accumulation in liver as it was in other mouse tissues (Terzian et al. 2008), suggesting tissue-specific, Mdm2-independent control of p53 levels. Given the diversity of E3 ligases (and potentially DUBs) that regulate p53 stability, it is likely that Mdm2-independent mechanisms play a role in tissue- or signal-specific control of p53 (wild-type and mutant) levels. The complexity and diversity of p53 regulation may provide an advantage to achieve tumorspecific control of p53 levels, with the desired outcome of stabilizing wild-type p53 while promoting degradation of mutant p53 to facilitate tumor regression.

\section{References}

Appella, E. and Anderson, C.W. 2001. Post-translational modifications and activation of p53 by genotoxic stresses. Eur. J. Biochem./FEBS 268: 2764-2772.

Barak, Y., Juven, T., Haffner, R., and Oren, M. 1993. mdm2 expression is induced by wild type p53 activity. EMBO J. 12: 461-468.

Bartkova, J., Horejsi, Z., Koed, K., Kramer, A., Tort, F., Zieger, K., Guldberg, P., Sehested, M., Nesland, J.M., Lukas, C., et al. 2005. DNA damage response as a candidate anti-cancer bar- rier in early human tumorigenesis. Nature 434: 864-870.

Brignone, C., Bradley, K.E., Kisselev, A.F., and Grossman, S.R. 2004. A post-ubiquitination role for MDM2 and hHR23A in the p53 degradation pathway. Oncogene 23: 4121-4129.

Chen, D., Kon, N., Li, M., Zhang, W., Qin, J., and Gu, W. 2005. ARF-BP1/Mule is a critical mediator of the ARF tumor suppressor. Cell 121: 1071-1083.

Dittmer, D., Pati, S., Zambetti, G., Chu, S., Teresky, A.K., Moore, M., Finlay, C., and Levine, A.J. 1993. Gain of function mutations in p53. Nat. Genet. 4: 42-46.

Dornan, D., Wertz, I., Shimizu, H., Arnott, D., Frantz, G.D., Dowd, P., O'Rourke, K., Koeppen, H., and Dixit, V.M. 2004. The ubiquitin ligase COP1 is a critical negative regulator of p53. Nature 429: 86-92.

Esser, C., Scheffner, M., and Hohfeld, J. 2005. The chaperoneassociated ubiquitin ligase CHIP is able to target p53 for proteasomal degradation. J. Biol. Chem. 280: 27443-27448.

Fischer, P.M. and Lane, D.P. 2004. Small-molecule inhibitors of the p53 suppressor HDM2: Have protein-protein interactions come of age as drug targets? Trends Pharmacol. Sci. 25: 343-346.

Giaccia, A.J. and Kastan, M.B. 1998. The complexity of p53 modulation: Emerging patterns from divergent signals. Genes \& Dev. 12: 2973-2983.

Gorgoulis, V.G., Vassiliou, L.V., Karakaidos, P., Zacharatos, P., Kotsinas, A., Liloglou, T., Venere, M., Ditullio Jr., R.A., Kastrinakis, N.G., Levy, B., et al. 2005. Activation of the DNA damage checkpoint and genomic instability in human precancerous lesions. Nature 434: 907-913.

Issaeva, N., Bozko, P., Enge, M., Protopopova, M., Verhoef, L.G., Masucci, M., Pramanik, A., and Selivanova, G. 2004. Small molecule RITA binds to p53, blocks p53-HDM-2 interaction and activates p53 function in tumors. Nat. Med. 10: 1321-1328.

Itahana, K., Mao, H., Jin, A., Itahana, Y., Clegg, H.V., Lindstrom, M.S., Bhat, K.P., Godfrey, V.L., Evan, G.I., and Zhang, Y. 2007. Targeted inactivation of Mdm2 RING finger E3 ubiquitin ligase activity in the mouse reveals mechanistic insights into p53 regulation. Cancer Cell 12: 355-366.

Iwakuma, T. and Lozano, G. 2003. MDM2, an introduction. Mol. Cancer Res. 1: 993-1000.

Jackson, E.L., Olive, K.P., Tuveson, D.A., Bronson, R., Crowley, D., Brown, M., and Jacks, T. 2005. The differential effects of mutant p53 alleles on advanced murine lung cancer. Cancer Res. 65: 10280-10288.

Jin, Y., Lee, H., Zeng, S.X., Dai, M.S., and Lu, H. 2003. MDM2 promotes $\mathrm{p} 21 \mathrm{waf1} / \mathrm{cip} 1$ proteasomal turnover independently of ubiquitylation. EMBO I. 22: 6365-6377.

Joerger, A.C. and Fersht, A.R. 2007. Structure-function-rescue: The diverse nature of common p53 cancer mutants. Oncogene 26: 2226-2242.

Jonason, A.S., Kunala, S., Price, G.J., Restifo, R.J., Spinelli, H.M., Persing, J.A., Leffell, D.J., Tarone, R.E., and Brash, D.E. 1996. Frequent clones of p53-mutated keratinocytes in normal human skin. Proc. Natl. Acad. Sci. 93: 14025-14029.

Jones, S.N., Roe, A.E., Donehower, L.A., and Bradley, A. 1995. Rescue of embryonic lethality in Mdm2-deficient mice by absence of p53. Nature 378: 206-208.

Kulikov, R., Winter, M., and Blattner, C. 2006. Binding of p53 to the central domain of $\mathrm{Mdm} 2$ is regulated by phosphorylation. J. Biol. Chem. 281: 28575-28583.

Lain, S. and Lane, D. 2003. Improving cancer therapy by nongenotoxic activation of p53. Eur. J. Cancer 39: 1053-1060.

Lang, G.A., Iwakuma, T., Suh, Y.A., Liu, G., Rao, V.A., Parant, J.M., Valentin-Vega, Y.A., Terzian, T., Caldwell, L.C., Strong, L.C., et al. 2004. Gain of function of a p53 hot spot mutation in a mouse model of Li-Fraumeni syndrome. Cell 
119: $861-872$.

Leng, R.P., Lin, Y., Ma, W., Wu, H., Lemmers, B., Chung, S., Parant, J.M., Lozano, G., Hakem, R., and Benchimol, S. 2003. Pirh2, a p53-induced ubiquitin-protein ligase, promotes p53 degradation. Cell 112: 779-791.

Li, Y. and Prives, C. 2007. Are interactions with p63 and p73 involved in mutant p53 gain of oncogenic function? Oncogene 26: 2220-2225.

Li, M., Brooks, C.L., Kon, N., and Gu, W. 2004. A dynamic role of HAUSP in the p53-Mdm2 pathway. Mol. Cell 13: 879-886.

Liu, Z., Hergenhahn, M., Schmeiser, H.H., Wogan, G.N., Hong, A., and Hollstein, M. 2004. Human tumor p53 mutations are selected for in mouse embryonic fibroblasts harboring a humanized p53 gene. Proc. Natl. Acad. Sci. 101: 2963-2968.

Lukashchuk, N. and Vousden, K.H. 2007. Ubiquitination and degradation of mutant p53. Mol. Cell. Biol. 27: 8284-8295.

Maetens, M., Doumont, G., Clercq, S.D., Francoz, S., Froment, P., Bellefroid, E., Klingmuller, U., Lozano, G., and Marine, J.C. 2007. Distinct roles of $\mathrm{Mdm} 2$ and $\mathrm{Mdm} 4$ in red cell production. Blood 109: 2630-2633.

Midgley, C.A. and Lane, D.P. 1997. p53 protein stability in tumour cells is not determined by mutation but is dependent on Mdm2 binding. Oncogene 15: 1179-1189.

Montes de Oca Luna, R., Wagner, D.S., and Lozano, G. 1995. Rescue of early embryonic lethality in mdm2-deficient mice by deletion of p53. Nature 378: 203-206.

Muller, P., Hrstka, R., Coomber, D., Lane, D.P., and Vojtesek, B. 2008. Chaperone-dependent stabilization and degradation of p53 mutants. Oncogene doi: 10.1038/sj.onc.1211010.

Olive, K.P., Tuveson, D.A., Ruhe, Z.C., Yin, B., Willis, N.A., Bronson, R.T., Crowley, D., and Jacks, T. 2004. Mutant p53 gain of function in two mouse models of Li-Fraumeni syndrome. Cell 119: 847-860.

Olivier, M., Eeles, R., Hollstein, M., Khan, M.A., Harris, C.C., and Hainaut, P. 2002. The IARC TP53 database: New online mutation analysis and recommendations to users. Hum. Mutat. 19: 607-614.

Petitjean, A., Achatz, M.I., Borresen-Dale, A.L., Hainaut, P., and Olivier, M. 2007. TP53 mutations in human cancers: Functional selection and impact on cancer prognosis and outcomes. Oncogene 26: 2157-2165.

Poyurovsky, M.V. and Prives, C. 2006. Unleashing the power of p53: Lessons from mice and men. Genes \& Dev. 20: 125-131.

Prives, C. 1998. Signaling to p53: Breaking the MDM2-p53 circuit. Cell 95: 5-8.

Prives, C. and Hall, P.A. 1999. The p53 pathway. J. Pathol. 187: 112-126.

Rajendra, R., Malegaonkar, D., Pungaliya, P., Marshall, H., Rasheed, Z., Brownell, J., Liu, L.F., Lutzker, S., Saleem, A., and Rubin, E.H. 2004. Topors functions as an E3 ubiquitin ligase with specific E2 enzymes and ubiquitinates p53. $J$. Biol. Chem. 279: 36440-36444.

Ringshausen, I., O'Shea, C.C., Finch, A.J., Swigart, L.B., and Evan, G.I. 2006. Mdm2 is critically and continuously required to suppress lethal p53 activity in vivo. Cancer Cell 10: $501-514$

Sdek, P., Ying, H., Chang, D.L., Qiu, W., Zheng, H., Touitou, R., Allday, M.J., and Xiao, Z.X. 2005. MDM2 promotes proteasome-dependent ubiquitin-independent degradation of retinoblastoma protein. Mol. Cell 20: 699-708.

Sherr, C.J. 1998. Tumor surveillance via the ARF-p53 pathway. Genes \& Dev. 12: 2984-2991.

Shimizu, H., Burch, L.R., Smith, A.J., Dornan, D., Wallace, M., Ball, K.L., and Hupp, T.R. 2002. The conformationally flexible S9-S10 linker region in the core domain of p53 contains a novel MDM2 binding site whose mutation increases ubiq- uitination of p53 in vivo. J. Biol. Chem. 277: 28446-28458. Shimizu, H., Saliba, D., Wallace, M., Finlan, L., LangridgeSmith, P.R., and Hupp, T.R. 2006. Destabilizing missense mutations in the tumour suppressor protein p53 enhance its ubiquitination in vitro and in vivo. Biochem. J. 397: 355-367.

Song, H., Hollstein, M., and Xu, Y. 2007. p53 gain-of-function cancer mutants induce genetic instability by inactivating ATM. Nat. Cell Biol. 9: 573-580.

Terzian, T., Suh, Y.-A., Iwakuma, T., Post, S.M., Neumann, M., and Lang, G.A. Van Pelt, C.S., and Lozano, G. 2008. The inherent instability of mutant p53 is alleviated by $M d m 2$ or p16 ${ }^{\text {INK4a }}$ loss. Genes \& Dev. (this issue) doi: 10.1101/ gad.1662908.

Toledo, F., Krummel, K.A., Lee, C.J., Liu, C.W., Rodewald, L.W., Tang, M., and Wahl, G.M. 2006. A mouse p53 mutant lacking the proline-rich domain rescues Mdm4 deficiency and provides insight into the $\mathrm{Mdm} 2-\mathrm{Mdm} 4-\mathrm{p} 53$ regulatory network. Cancer Cell 9: 273-285.

Toledo, F., Lee, C.J., Krummel, K.A., Rodewald, L.W., Liu, C.W., and Wahl, G.M. 2007. Mouse mutants reveal that putative protein interaction sites in the p53 proline-rich domain are dispensable for tumor suppression. Mol. Cell. Biol. 27: 14251432.

Uchida, C., Miwa, S., Kitagawa, K., Hattori, T., Isobe, T., Otani, S., Oda, T., Sugimura, H., Kamijo, T., Ookawa, K., et al. 2005. Enhanced Mdm2 activity inhibits pRB function via ubiquitin-dependent degradation. EMBO J. 24: 160-169.

Vassilev, L.T. 2007. MDM2 inhibitors for cancer therapy. Trends Mol. Med. 13: 23-31.

Vassilev, L.T., Vu, B.T., Graves, B., Carvajal, D., Podlaski, F., Filipovic, Z., Kong, N., Kammlott, U., Lukacs, C., Klein, C., et al. 2004. In vivo activation of the p53 pathway by smallmolecule antagonists of MDM2. Science 303: 844-848.

Vogelstein, B., Lane, D., and Levine, A.J. 2000. Surfing the p53 network. Nature 408: 307-310.

Vousden, K.H. and Lu, X. 2002. Live or let die: The cell's response to p53. Nat. Rev. 2: 594-604.

Weger, S., Hammer, E., and Heilbronn, R. 2002. Topors, a p53 and topoisomerase I binding protein, interacts with the adeno-associated virus (AAV-2) Rep78/68 proteins and enhances AAV-2 gene expression. J. Gen. Virol. 83: 511-516.

Weisz, L., Oren, M., and Rotter, V. 2007. Transcription regulation by mutant p53. Oncogene 26: 2202-2211.

Wu, X., Bayle, J.H., Olson, D., and Levine, A.J. 1993. The p53mdm-2 autoregulatory feedback loop. Genes \& Dev. 7: 11261132.

Xiong, S., Van Pelt, C.S., Elizondo-Fraire, A.C., Liu, G., and Lozano, G. 2006. Synergistic roles of Mdm2 and Mdm4 for p53 inhibition in central nervous system development. Proc. Nat1. Acad. Sci. 103: 3226-3231.

Xiong, S., Van Pelt, C.S., Elizondo-Fraire, A.C., Fernandez-Garcia, B., and Lozano, G. 2007. Loss of Mdm4 results in p53-dependent dilated cardiomyopathy. Circulation 115: 2925-2930.

Yamasaki, S., Yagishita, N., Sasaki, T., Nakazawa, M., Kato, Y., Yamadera, T., Bae, E., Toriyama, S., Ikeda, R., Zhang, L., et al. 2007. Cytoplasmic destruction of p53 by the endoplasmic reticulum-resident ubiquitin ligase 'Synoviolin.' EMBO J. 26: $113-122$

Zhang, Z., Wang, H., Li, M., Agrawal, S., Chen, X., and Zhang, R. 2004. MDM2 is a negative regulator of p21WAF1/CIP1, independent of p53. J. Biol. Chem. 279: 16000-16006.

Zhu, Q., Yao, J., Wani, G., Wani, M.A., and Wani, A.A. 2001 Mdm2 mutant defective in binding p300 promotes ubiquitination but not degradation of p53: Evidence for the role of p300 in integrating ubiquitination and proteolysis. J. Biol. Chem. 276: 29695-29701. 


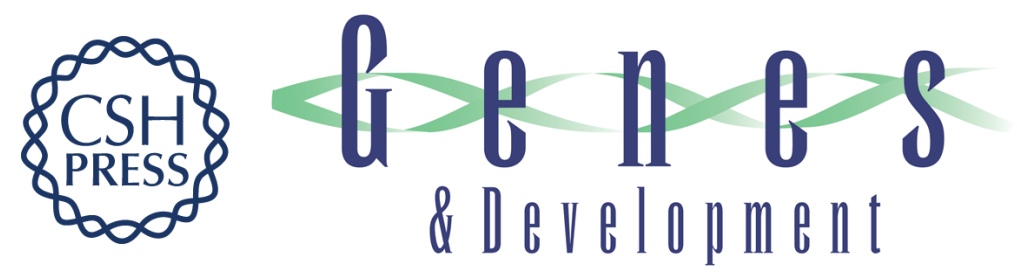

\section{Does control of mutant p53 by Mdm2 complicate cancer therapy?}

Carol Prives and Eileen White

Genes Dev. 2008, 22:

Access the most recent version at doi:10.1101/gad.1680508

Related Content The inherent instability of mutant p53 is alleviated by Mdm2 or p16INK4a loss Tamara Terzian, Young-Ah Suh, Tomoo Iwakuma, et al. Genes Dev. May , 2008 22: 1337-1344

References This article cites 59 articles, 24 of which can be accessed free at: http://genesdev.cshlp.org/content/22/10/1259.full.html\#ref-list-1

Articles cited in:

http://genesdev.cshlp.org/content/22/10/1259.full.html\#related-urls

\section{License}

Email Alerting

Receive free email alerts when new articles cite this article - sign up in the box at the top Service right corner of the article or click here.

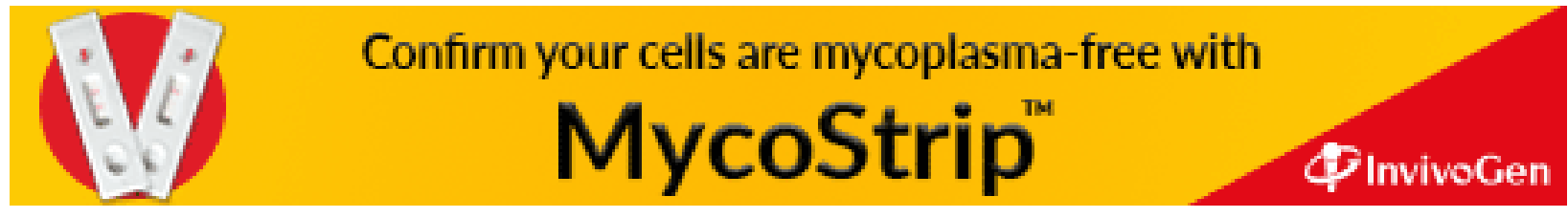

